\title{
Ekstraksi Antosianin dari Kelopak Bunga Rosella (Hibiscus sabdariffa L.) Berbantu Ultrasonik: Tinjauan Aktivitas Antioksidan
}

\section{Ultrasonic Aided Anthocyanin Extraction of Hibiscus sabdariffa L. Flower Petal: Antioxidant Activity}

M. Djaeni, Nita Ariani, Rahmat Hidayat, Febiani Dwi Utari*

Jurusan Teknik Kimia, Fakultas Teknik, Universitas Diponegoro

Korespondensi dengan penulis (febianidu@gmail.com)

Artikel ini dikirim pada tanggal 9 Februari 2017 dan dinyatakan diterima tanggal 18 Juli 2017. Artikel ini juga dipublikasi secara online melalui www.jatp.ift.or.id. Hak cipta dilindungi undang-undang. Dilarang diperbanyak untuk tujuan komersial.

Diproduksi oleh Indonesian Food Technologists @ (อ2017

\section{Abstrak}

Bunga rosella (Hibiscus sabdariffa $\mathrm{L}$ ) mengandung antosianin yang dapat digunakan sebagai pewarna alami dan sekaligus sebagai antioksidan. Antioksidan merupakan molekul yang dapat bereaksi dengan radikal bebas dan berfungsi menetralkan radikal bebas. Metode terdahulu dalam mengekstrak bunga rosella adalah menggunakan metode maserasi atau soxhlet, metode ini memiliki beberapa kelemahan di antaranya waktu operasi lama, suhu tinggi yang mampu mendegradasi senyawa antosianin dan hasil ekstrak yang kurang stabil sehingga diperlukan metode yang lebih efisien. Tujuan penelitian ini adalah mengkaji pengaruh variasi rasio bahan : pelarut dan waktu ekstraksi terhadap kadar antosianin dari bunga rosella berbantu ultrasonik, serta mengkaji aktivitas antioksidan yang terdapat pada bunga rosella menggunakan DPPH (2,2-difenil-1-prikrilhidrazil). Penelitian ini dilakukan melalui dua tahapan. Tahap pertama adalah ekstraksi antosianin dengan metode ekstraksi berbantu ultrasonik menggunakan pelarut air. Sedangkan tahap kedua adalah uji aktivitas antioksidan dari ekstrak bunga rosella yang mengandung antosianin menggunakan larutan DPPH. Hasil ekstraksi antosianin dinyatakan dalam $\mathrm{mg} / \mathrm{gr}$ sampel dan hasil uji aktivitas antioksidan dinyatakan dalam \% inhibisi. Hasil penelitian menunjukkan bahwa jumlah pelarut dan lamanya waktu ekstraksi sangat mempengaruhi hasil ekstrak antosianin yang diperoleh, dari variabel rasio bahan : pelarut 1:7 hingga 1:13 menunjukkan semakin banyak jumlah pelarut yang digunakan semakin tinggi pula ekstrak yang didapatkan dan dari variabel waktu 30 menit hingga 60 menit menunjukkan semakin lama waktu ekstraksi semakin banyak ekstrak antosianin yang diperoleh. Hasil terbanyak yang diperoleh yaitu pada rasio bahan : pelarut 1:13 dengan lama waktu ekstraksi 60 menit sebesar 115,353 mg/100gr. Yield terbesar diperoleh pada variable yang sama sebesar $44,856 \%$. Senyawa yang terkandung pada bunga rosella merupakan antioksidan kuat (nilai IC50 berkisar antara 50-100ppm).

Kata kunci: ekstraksi, rosella, tray dryer, ultrasonic

\section{Abstract}

Rosella flower (Hibiscus sabdariffa L) contain anthocyanin which can be used as natural colorant and also antioxidant. Antioxidant is a substance which able to react and neutralize free radicals. Common method to extract Rosella flower is by means of maceration or soxhlet. The methods have disadvantages such as long processing time, anthocyanin degradation due to high temperature and less stable extract, thus a more efficient method is needed. The aim of the current study was to evaluate the effect of substrate-solvent ratio and the extraction time towards anthocyanin level and antioxidant activity. The extraction was carried out using water as solvent (several ratios) and aided with ultrasonic. Antioxidant activity was performed using DPPH solution. The result was expressed in $\mathrm{mg} / \mathrm{gr}$ sample and \% inhibition for the antioxidant activity. The study showed that substrate-solvent ratio has significant effect towards the amount of extract. It was shown that higher solvent ratio resulting in higher amount of extract. The same effect was observed from longer extraction time. The highest extract amount was obtained from substrate-solvent ration of $1: 13$ and 60 minutes extraction time with $115,353 \mathrm{mg} / 100 \mathrm{~g}$. The combination also resulted in the highest yield with $44,856 \%$. Rosella flowe extract contained a strong antioxidant compound (IC50 value range from 50-100 ppm).

keyword: extraction, rosella, tray dryer, ultrasonic

\section{Pendahuluan}

Tanaman rosela merupakan tanaman hias luar ruangan yang merupakan jenis dari tanaman sepatu. Di Indonesia dengan iklim tropis, rosella dapat tumbuh dengan subur. Tanaman rosella (Hibiscus Sabdariffa L.) merupakan tanaman yang sangat dikenal saat ini karena kelopak bunga rosella dapat digunakan sebagai minuman kesehatan yang dapat menyembuhkan berbagai penyakit seperti hipertensi, diabetes, dan diuretik (Patel, 2013). Zat aktif yang paling berperan dalam kelopak bunga rosella meliputi gossypetin, antosianin, dan glukosida hibisci (Moeksin dan Ronald, 2009). Warna merah pada bunga rosella (Hibiscus Sabdariffa L.) disebabkan oleh kandungan antosianin.
Senyawa antosianin merupakan senyawa yang termasuk dalam golongan flavonoid. Antosianin berfungsi sebagai antioksidan yang diyakini dapat menyembuhkan penyakit degeneratif (Mardiah et al., 2009). Antioksidan yang dikenal sebagai peredam atau pemerangkap (scavenger) merupakan molekul yang dapat bereaksi dengan radikal bebas dan berfungsi menetralkan radikal bebas. Reaksi oksidasi yang berlebihan di dalam tubuh dapat menyebabkan terbentuknya radikal bebas yang sangat aktif, yang dapat merusak struktur serta fungsi sel (Marx, 1985). Sel memiliki antioksidan alami seperti superoksida dismutase (SOD), katalase, reduktase, glutation 
peroksida dan antioksidan yang bisa mempertahankan dan memberi perlindungan dari pengaruh radikal bebas (Wehantouw dan Suryanto, 2009). Namun ketika radikal bebas lebih banyak daripada kemampuan pertahanan, antioksidan alami tersebut bisa mengalami gangguan sehingga memutuskan rantai reduksioksidasi normal dan mengakibatkan kerusakan oksidatif jaringan yang sering dikenal dengan stress oksidatif. Oleh karena itu diperlukan suplemen antioksidan untuk membantu sistem pertahanan tubuh kembali normal.

Antosianin dari bunga rosella dapat diambil dengan menggunakan teknik ekstraksi. Tetapi ekstrak dalam bentuk larutan kurang stabil hingga perlu dilakukan pengeringan menjadi serbuk. Dalam tulisan ini, diuraikan hasil penelitian yang dilakukan dengan tujuan untuk mengkaji pengaruh dari perbedaan rasio bahan : pelarut dan waktu ekstraksi terhadap yield ekstrak bunga rosella dan kadar ekstrak antosianin dari bunga rosella sehingga dapat mengetahui kondisi ekstraksi terbaik, selain itu juga dapat mengkaji aktivitas antioksidan yang terdapat pada bunga rosella (Hibiscus Sabdariffa L.) menggunakan metode DPPH (2,2-difenil-1-pikrilhidrazil).

\section{Metode Penelitian}

Penelitian ini menggunakan bahan utama bunga rosella (Hibiscus Sabdariffa $L$ ). Rancangan percobaan pada penelitian ini diawali dengan persiapan awal bunga rosella yang meliputi tahap size reduction menggunakan blender dan screening menggunakan ayakan. Lalu dilanjutkan dengan proses ekstraksi zat antosianin yang terkandung dalam bunga rosella menggunakan metode ekstraksi berbantu ultrasonik. Sampel sebanyak $50 \mathrm{~g}$ di ekstrak menggunakan alat ultrasonik pada suhu $30 \mathrm{oC}$ dengan bantuan pengaduk. Pelarut yang digunakan adalah aquades.

Pada metode ekstraksi ini dilakukan beberapa variasi ekstraksi $(30,45,60)$ menit, rasio bahan : pelarut $(1: 7 ; 1: 9 ; 1: 11 ; 1: 13)$. Hasil ekstraksi dipisahkan dari ampas dengan menggunakan alat vacuum filter dan kertas saring. Filtrat yang diperoleh dipisahkan dari pelarutnya menggunakan alat pengering tray dryer selama 3 jam dan ditimbang setiap 5 menit sampai berat konstan. Serbuk hasil pengeringan dianalisa kadar total antosianin, dan analisa metode DPPH untuk mengetahui aktivitas antioksidan dari ekstrak bunga rosella.

\section{Hasil dan Pembahasan}

Pengaruh Variabel Berubah Ekstraksi Terhadap Kadar Antosianin Pada Kelopak Bunga Rosella

Proses ekstraksi antosianin dari kelopak bunga rosella dilakukan dengan metode sonikasi yaitu metode yang menggunakan alat ultrasonik untuk mengekstrak antosianin dengan memanfaatkan gelombang ultrasonik. Proses ekstraksi dilakukan pada suhu ruang $\left(30^{\circ} \mathrm{C}\right)$. Pelarut yang dipakai dalam proses ekstraksi ini adalah air. Pada penelitian ini ekstraksi dilakukan dengan beberapa variabel yaitu waktu ekstraksi (30, 45, 60 menit) dan rasio bahan : pelarut $(1: 7,1: 9,1: 11$, $1: 13 \mathrm{~b} / \mathrm{v})$.

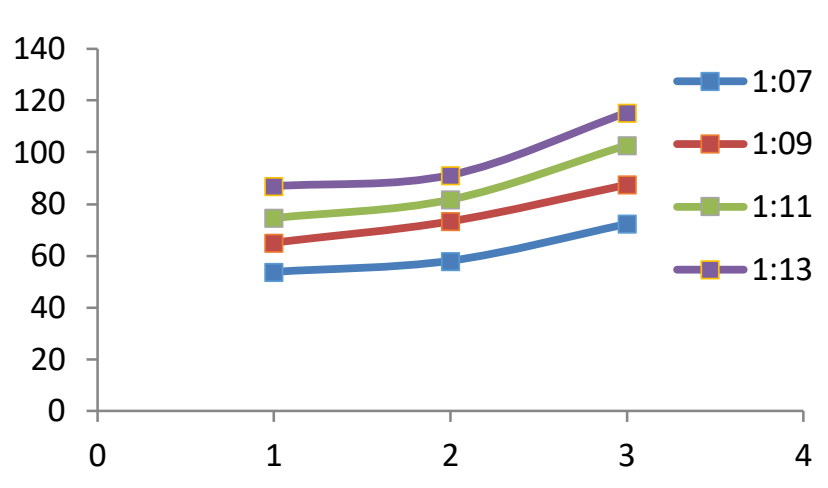

Gambar 1. Grafik Hubungan Waktu Ekstraksi Terhadap Kadar Antosianin Kelopak Bunga Rosella pada Berbagai Rasio Bahan : Pelarut

Berdasarkan Gambar 1 di atas, dapat dilihat bahwa semakin lama waktu ekstraksi maka kadar antosianin yang didapat juga semakin banyak dan semakin banyak jumlah pelarut maka jumlah antosianin yang diekstrak juga akan semakin banyak, sehingga kadar antosianinnya juga akan semakin tinggi. Pada penelitian ini kadar antosianin terkecil didapat pada waktu ektraksi 30 menit dan perbandingan rasio bahan : pelarut $1: 7 \mathrm{~b} / \mathrm{v}$ yaitu $53,776 \mathrm{mg} / 100 \mathrm{~g}$, sedangkan kadar antosianin terbesar yang didapat adalah pada waktu ekstraksi 60 menit dan rasio bahan : pelarut 1:13 $\mathrm{b} / \mathrm{v}$ yaitu $115,353 \mathrm{mg} / 100 \mathrm{~g}$.

Menurut Suzery et al. (2010) kandungan antosianin dalam kelopak bunga rosella adalah 128,76 $\mathrm{mg} / 100 \mathrm{~g}$. Hal ini menunjukkan bahwa hasil yang diperoleh dari penelitian ini lebih kecil dibandingkan penelitian yang sebelumnya dilkaukan oleh Suzery et al. (2010). Pada variabel waktu ekstraksi 60 menit kadar antosianin yang didapat sebesar $115,353 \mathrm{mg} / 100$ g sedangkan pada penelitian Suzery et al. (2010) dengan waktu 24 jam kadar antosianin yang didapat adalah 128,76 mg/100g. Dari data tersebut menunjukkan bahwa perbedaan kadar antosianin antara keduanya tidak terlalu signifikan, akan tetapi perbedaan waktu pada kedua metode penelitian sangat signifikan. Dapat disimpulkan bahwa metode penelitian yang dilakukan dapat memberikan efisiensi waktu ekstraksi selama 23 jam untuk mendapatkan jumlah kadar antosianin yang hampir sama.

Berdasarkan percobaaan yang telah dilakukan dengan metode maserasi pada suhu $30^{\circ} \mathrm{C}$ (suhu ruang) dengan rasio bahan : pelarut 1:13 selama 8 jam kadar antosianin yang dihasilkan adalah $9,360 \mathrm{mg} / 100 \mathrm{~g}$, sedangkan pada metode berbantu ultrasonik dengan rasio bahan : pelarut yang sama didapatkan kadar antosianin sebesar $115,353 \mathrm{mg} / 100 \mathrm{~g}$. Dari data ini dapat disimpulkan bahwa dengan kondisi operasi dan rasio bahan : pelarut yang sama, kadar antosianin yang didapat dengan menggunakan metode berbantu ultrasonik jauh lebih besar dibandingkan dengan menggunakan metode maserasi.

\section{Pengaruh Variabel Berubah Ekstraksi Terhadap Yield Ekstrak Bunga Rosella}

Pada percobaan ini, ekstraksi bunga rosella berbantu ultrasonik dilakukan dari $100 \mathrm{~g}$ bunga rosella kering dengan variasi rasio pelarut air : bunga rosella 
kering yaitu 1:7, 1:9, 1:11, 1:13 dan variasi waktu ekstraksi selama 30,45 dan 60 menit pada suhu $30^{\circ} \mathrm{C}$ menit. Perhitungan yield dilakukan dengan mengeringkan ekstrak menggunakan tray dryer pada suhu $50^{\circ} \mathrm{C}$ diperoleh yield yang berbeda. Yield ekstrak bunga rosella (\%) yang diperoleh pada berbagai jumlah pelarut dan waktu ekstraksi disajikan pada gambar berikut:

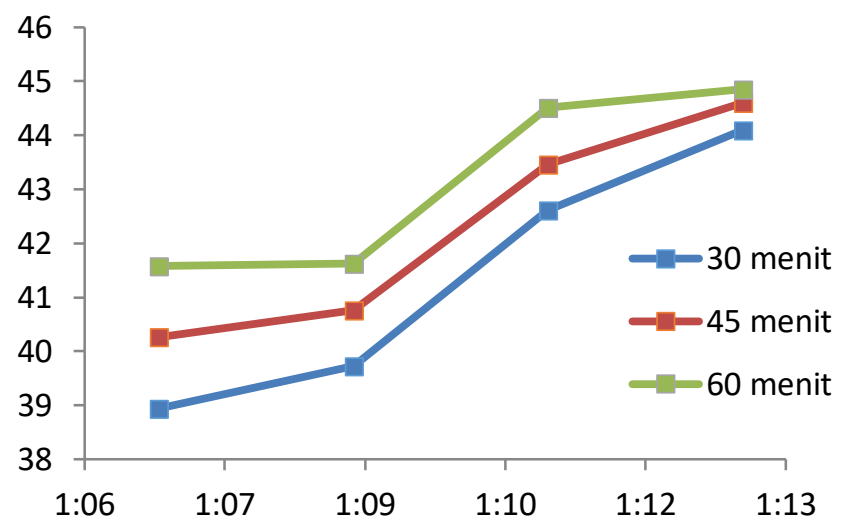

Gambar 2 Grafik Hubungan Perbandingan Pelarut terhadap Yield Ekstrak Antosianin pada Berbagai Waktu

Dari gambar di atas terlihat bahwa pada penggunaan pelarut air $350 \mathrm{~mL}$ hingga $650 \mathrm{~mL}$ tiap 100 $\mathrm{g}$ bunga rosella maka yield ekstrak bunga rosella yang dihasilkan semakin meningkat secara linier seiring dengan jumlah pelarut yang ditambahkan. Pelarut air berfungsi mengambil antosianin dari dalam sel bunga rosella atas dasar kelarutan senyawa polar terhadap pelarut polar. Pada penambahan jumlah pelarut yang sedikit, jumlah ekstrak yang diperoleh juga sedikit hal ini disebabkan pelarut yang sedikit akan cepat jenuh sehingga tidak mampu lagi melarutkan antosianin lebih banyak, sedangkan pada penambahan jumlah pelarut yang lebih banyak, pelarut mampu menampung antosianin lebih banyak sampai pelarut air jenuh.

Menurut Maran dan Priya (2015), semakin banyak jumlah pelarut akan menyebabkan semakin banyaknya area kontak antara bahan dengan pelarut, yang akan mendorong semakin tingginya difusivitas. Selain itu, intensitas kavitasi akan menurun seiring naiknya viskositas medium pada metode ultrasonik, dan kavitasi itu sendiri lebih sulit dihasilkan pada medium yang kental. Sedangkan menurut $\mathrm{Xu}$ et al. (2014), semakin besar rasio bahan - pelarut maka intensitas ultrasonik yang dikenakan pada bahan jaringan tumbuhan makin tinggi dan menyebabkan fragmentasi dari bahan. Namun penggunaan volume pelarut yang berlebihan perlu dihindari karena menyebabkan terhambatnya transfer energi gelombang ultrasonik akibat diserap oleh pelarut sebelum sampai ke matriks (Winata dan Yunianta, 2015). Hal-hal inilah yang menyebabkan peningkatan jumlah antosianin terekstrak yang cenderung meningkat seiring bertambahnya jumlah pelarut.

Berdasarkan gambar diketahui bahwa semakin lama waktu ekstraksi maka jumlah yield yang diperoleh cenderung semakin tinggi. Waktu terbaik diperoleh pada jumlah perbandingan pelarut $1: 13$ dengan waktu 60 menit, yield yang didapat sebesar $44,856 \%$ berat kering bunga rosella.

\section{Uji Aktivitas Antioksidan}

Ekstrak bunga rosella dilakukan uji aktivitas antioksidan menggunakan DPPH (2,2-difenil-1pikrilhidrazil). Aktivitas antioksidan dinyatakan dalam $\mathrm{IC}_{50}$. Menurut Amrun dan Umayah, (2007) konsentrasi larutan seri dan \& inhibisi memiliki hubungan yang linier. Data yang diperoleh yaitu \% inhibisi kemudian diplotkan ke grafik sesuai dengan konsentrasi larutan seri masing-masing untuk mengetahui linierisasi dan persamaannya. Dari persamaan tersebut maka bisa dihitung nilai $I_{50}$. Kurva hubungan persen inhibisi berbagai variasi konsentrasi larutan seri (ppm) dapat dilihat pada Gambar 3.

Berdasarkan data yang diperoleh, maka aktivitas antioksidan ekstrak bunga rosella berkisar antara 10269 ppm. Menurut Sihotang et al. (2008) suatu senyawa dikatakan sebagai antioksidan sangat kuat jika nilai $\mathrm{IC}_{50}$ kurang dari $50 \mathrm{ppm}$, kuat untuk $\mathrm{IC}_{50}$ 50-100 ppm, sedang jika $\mathrm{IC}_{50}$ bernilai $100-150 \mathrm{ppm}$ dan lemah jika nilai $\mathrm{IC}_{50}$ 151-200 ppm.

Semua ekstrak bunga rosella yang didapat menunjukkan bahwa aktivitas antioksidan yang terdapat pada bunga rosella termasuk dalam antioksidan kuat. Melihat hal tersebut, maka ekstrak bunga rosella sangat cocok untuk dijadikan antioksidan bentuk tablet atau serbuk. Hal ini juga meninjau hasil dari pengeringan menggunakan tray dryer yang sudah dalam bentuk serbuk ekstrak antosianin.

Tabel 1. Hasil Uji Aktivitas Antioksidan

\begin{tabular}{ccc}
\hline Variabel & Persamaan & $\mathrm{IC}_{50}(\mathrm{ppm})$ \\
\hline 1 & $\mathrm{y}=0,3609 \mathrm{x}+13,2$ & 101,97 \\
2 & $\mathrm{y}=0,3542 \mathrm{x}+15,627$ & 97,04 \\
4 & $\mathrm{y}=0,319 \mathrm{x}+18,968$ & 97,28 \\
5 & $\mathrm{y}=0,3301 \mathrm{x}+18,133$ & 96,54 \\
6 & $\mathrm{y}=0,258 \mathrm{x}+25,213 \mathrm{x}+27,515$ & 96,07 \\
7 & $\mathrm{y}=0,2971 \mathrm{x}+22,225$ & 93,49 \\
8 & $\mathrm{y}=0,2801 \mathrm{x}+25,331$ & 88,07 \\
9 & $\mathrm{y}=0,2801 \mathrm{x}+25,331$ & 88,07 \\
10 & $\mathrm{y}=0,3037 \mathrm{x}+26,35$ & 77,87 \\
11 & $\mathrm{y}=0,3027 \mathrm{x}+28,084$ & 72,40 \\
12 & $\mathrm{y}=0,3011 \mathrm{x}+29,152$ & 69,24 \\
\hline
\end{tabular}




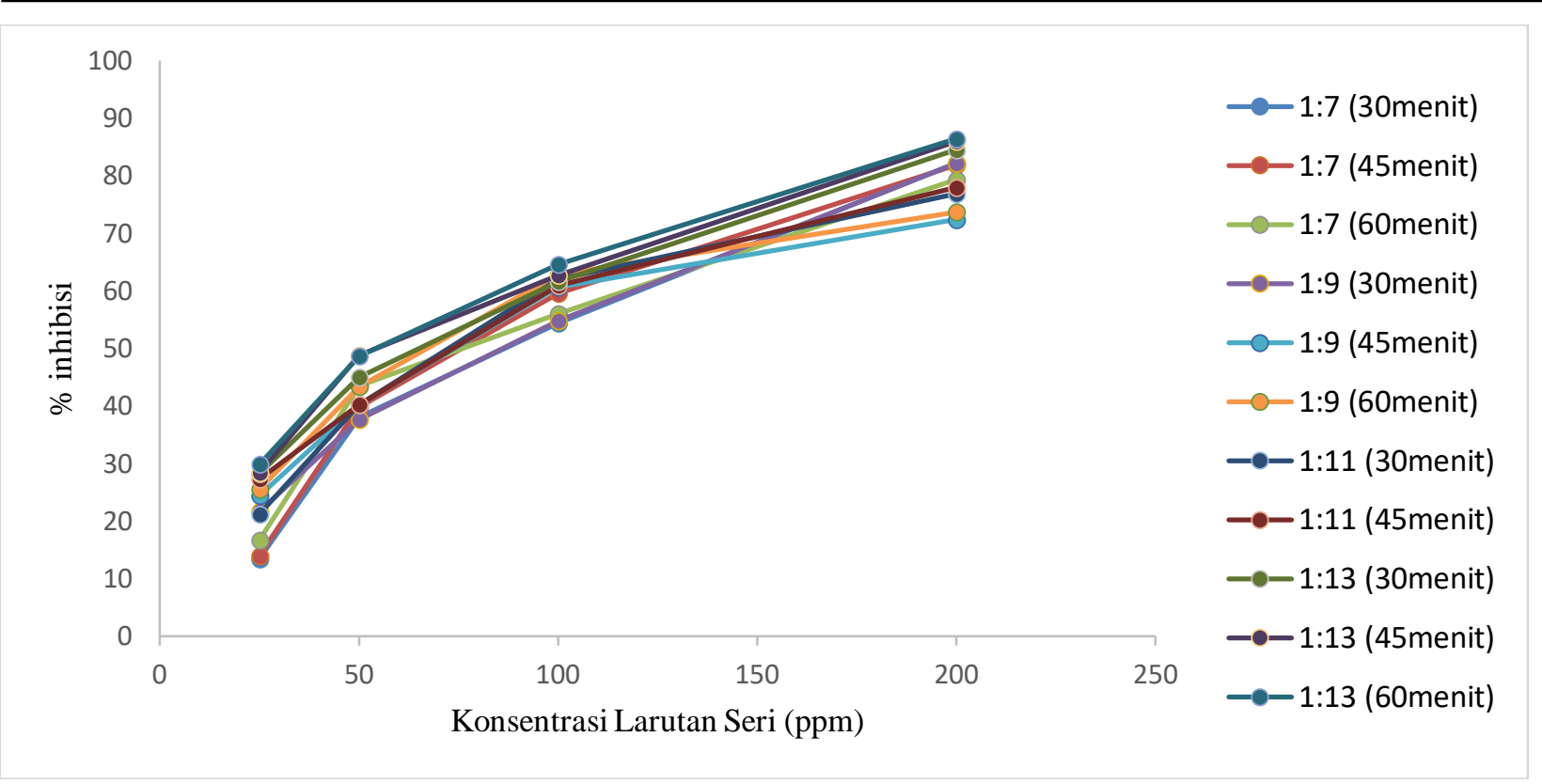

Gambar 3. Grafik Larutan Seri (ppm)

\section{Kesimpulan}

Ekstraksi kelopak bunga rosella menggunakan air dapat menghasilkan antioksidan yang tergolong kuat $\left(\mathrm{IC}_{50}=50-100 \mathrm{ppm}\right)$. Pada penelitian diketahui bahwa dengan menggunakan metode sonikasi kadar antosianin yang dihasilkan $\pm 12 \times$ lebih banyak dibandingkan dengan menggunakan metode konvensional (maserasi). Kadar antosianin terbesar dihasilkan pada variable perbandingan solvent $1: 13$ $\mathrm{b} / \mathrm{v}$ dengan waktu ekstraksi 60 menit yaitu 115,353 $\mathrm{mg} / 100 \mathrm{~g}$. Jumlah kadar antosianin yang dihasilkan semakin besar seiring dengan bertambahnya waktu ekstraksi dan semakin besar perbandingan solvent. Yield ekstrak bunga rosella yang dihasilkan semakin meningkat secara linier seiring dengan jumlah pelarut yang ditambahkan. Dan semakin lama waktu ekstraksi maka jumlah yield yang diperoleh cenderung semakin tinggi. Kondisi terbaik diperoleh pada jumlah perbandingan pelarut $1: 13$ dengan waktu 60 menit. yield yang didapat sebesar $44,856 \%$ berat kering bunga rosella.

\section{Daftar Pustaka}

Amrun, M. \& Umayah, E. 2007. Antioxidant Activity Assay of Dragon Fruit Extract. Jurnal IImu Dasar, 8(1), pp.83-90.

Maran, J.P dan Priya, B. 2015. Ultrasound-assited Extraction of Pectin from Sisal Waste. Carbohydrate Polymers 115 (2015) 732-738.

Mardiah, Amalia, L., dan Sulaeman, A. 2010. Ekstraksi Kulit Batang Rosella (Hibiscus sabdariffa L.) Sebagai Pewarna Merah Alami. Jurnal Pertanian. ISSN 2087-4936 Volume 1 Nomor 1, Oktober 2010
Marx, J.L. 1985. Oxygen Free Radicals Linked to Many Disease. Science. 235:529-531

Moeksin, R., dan Ronald, S. H., 2009. Pengaruh Kondisi, Perlakuan dan Berat Sampel terhadap Ekstraksi Antosianin dari Kelopak Bunga Rosella dengan Pelarut Aquadest dan Ethanol. Jurnal Sains dan Matematika (JSM), 16, 11-18

Patel, S. 2014. Hibiscus sabdariffa : An ideal yet underexploited candidate for neutraceutrical applications. Biomedicine \& Preventive Nutrition. Vol $4: 23-27$

Sihotang, H., Tarigan, J. \& Zuhra, C. 2008. Aktivitas Antioksidan Senyawa Flavonoid dari Daun Katuk (Sauropus androgunus). Jurnal Biologi, 3(1), pp. 7-10.

Suzery, M., Lestari, S., and Cahyono, B. 2010. Penentuan Total Antosianin dari Kelopak Bunga Rosela (Hibiscus sabdariffa L.) dengan Metode Maserasi dan Sokhletasi. Jurnal Sains \& Matematika Vol.18(1):1-6.

Wehantouw, F., and Suryanto, E., 2009. Free radicals scavenging activities of phenolic extracts from Bread Fruit Leaves. Chem. Prog. Vol. 2 No.1

Winata, E. W., dan Yunianta. 2015. Ekstraksi Antosianin Buah Murbei (Morus alba L.) metode ultrasonic Bath (Kajian Waktu dan Rasio Bahan : Pelarut). Jurnal Pangan dan Agroindustri. Vol.3 : 773-778

Xu, Y., Zhang, L., Bailina, Y., Ge, Zhie, Ding, T., Ye, X., Liu, D. 2014. Effects of Ultrasound and/or The Extraction of Pectin from Grapefruit Peel. Journal of Food Engineering 126 (2014) 72-81. 